\title{
OBITUARY
}

\section{Peter Brock, 1920-2006}

Peter Brock died peacefully at his home in Toronto on 28 May 2006 following a ten-month struggle with cancer. Born on the island of Guernsey into a family with a strong military tradition, Peter became active in the peace movement as an undergraduate at Oxford University in the late 1930s and imbibed the ideals of secular pacifism. Faithful to these ideals, he chose the status of conscientious objector with the start of World War II, for which he was briefly imprisoned in Britain, and worked in a hospital as a form of alternative service. Following the war he joined the Anglo-American Quaker Relief Mission and made his first contact with east central Europe, working in Poland.

Peter began his study of east central European history in Poland, receiving a PhD from Jagiellonian University in Kraków in 1950. (For a delightful example of his wit, see his article "From Oxford to Toronto via Cracow: The Vicissitudes of a Young Historian in People's Poland," Polish Review 43, no. 4 [1998]: 461-67.) His publications focused on the populist and socialist movements in nineteenth-century Poland and among Polish political exiles. He brought some of this research together in his books Nationalism and Populism in Partitioned Poland: Selected Essays (1973) and Polish Revolutionary Populism: A Study in Agrarian Socialist Thought from the 1830s to the 1850s (1977). His essay "Polish Nationalism" in Peter F. Sugar and Ivo J. Lederer, eds., Nationalism in Eastern Europe (1969) remains a seminal work on the subject. (Peter largely confined his interest in nationalism to the nineteenth-century when it was a liberating force in east central Europe, reflecting his empathy with those who oppose injustice or oppression.) He maintained his interest in Polish history to the end: with John D. Stanley and Piotr Wróbel, he coedited Nation and History: Polish Historians from the Enlightenment to the Second World War (2006) and with Zdzisław Pietrzyk coauthored "Stanisław Kot (1885-1975)" in the collection.

But, unlike many of us, Peter was not content to specialize in the history of just one country. He received a second doctoral degree in history from Oxford University in 1954 with a study that resulted in the publication of The Political and Social Doctrines of the Unity of Czech Brethren in the Fifteenth and Early Sixteenth Centuries (1957), which married his interest in pacifism to his interest in east central Europe, something he would continue with studies of examples of pacifism in the region. From Czech history he went on to studies in the history of Lusatian Sorbs, Kashubs, Ukrainians, Slovaks, and Hungarians, some of which were collected in Folk Cultures and Little Peoples: Aspects of National Awakening in East Central Europe (1992) and The Slovak National Awakening: An Essay in the Intellectual History of East Central Europe (1976). As a dedicated historian, Peter did not let the necessity of learning another language deter him from using primary sources on a topic that interested him. When I once expressed admiration for his ability to learn Hungarian, he replied with characteristic self-deprecation but without a touch of irony that he could only read Hungarian, not speak it.

Although the history of east central Europe was his first scholarly love and remained almost the exclusive area of his teaching, Peter's contributions to that field tell the tale of only part of his scholarly achievements. It is almost as if there were another scholar named Peter Brock who was the world's foremost scholar of pacifist history, almost but not quite, since he first manifested his interest in pacifist history in his contributions to the history of east central Europe. In The Pacifist Impulse in Historical Perspective, ed. Harvey L. Dyck (1996), a collection of twenty-three essays dedicated to Peter, Martin Ceadel writes, "No ideology owes more to one academic than pacifism owes to Peter Brock. That the scope and richness of its historical tradition can now be recognized is largely the result of Brock's sympathetic and dedicated scholarship" (17). This collection brings together papers presented at an international conference at the University of Toronto in 1991, the year in which Peter published the second and third volumes of a comprehensive history of pacifism to 1914, which began with The Quaker Peace Testimony 1660-1914 (1990) and was followed by Freedom from Violence: Sectarian Nonresistance from the Middle Ages to the Great War (1991) and Freedom from War: Nonsectarian Pacifism 1814-1914 (1991). 
The history of pacifism took Peter geographically far from east central Europe but not from topics that he first touched on in its history. After learning Gujarati and spending a year doing research in India, he published The Mahatma and Mother India: Essays on Gandhi's Nonviolence and Nationalism (1983). He also brought east central Europe into his study of pacifism, for example, writing on the Polish Anabaptists. Peter was an extraordinarily productive scholar; a list of his publications runs to some twenty-five pages: Scholarly Publications by Peter de Beauvoir Brock, ed. John D. Stanley (2006).

After a year of teaching at the University of Toronto (1957-1958), Peter taught at the University of Alberta, Smith College, and Columbia University, which he left in 1966, in part because of the U.S. war in Vietnam, to return to the University of Toronto, where he taught until his retirement in 1985 . With his wife, Carmen née Williamson, a Quaker born in Jamaica, he shared a love of travel, music, and a commitment to pacifism, until her death in 1998 after nearly forty years of marriage. He chose their memorial plaque, which reads, "Let us be aware of the source of being common to us all and to all living things." Ever striving to live according to his convictions, Peter became a vegetarian in his final years. Truly a man of peace, Peter is greatly missed by the students he mentored and by his colleagues and friends.

JOHN J. KuLCZYCKI University of Illinois, Chicago July 2006 